\title{
Appendix 2 Mapping of Baltic Sea Region tools
}

The progress that has been made in strengthening cooperation and integration in the Baltic Sea Region (BSR) is a result of sound domestic foundations, which foster flows of goods, capital, people and ideas that are supported and enhanced by a number of knowledge platforms, policy instruments and/or programs and organizational structures. This Appendix introduces an overall categorization and mapping of various tools for regional cooperation and integration, and presents some reflections on how they have functioned ${ }^{1}$ in the BSR.

The tools are mapped according to the type of tool and the level of implementation.

The following types of tools have been included:

- Platform building tools are strategies, institutions or organizational structures that establish overall objectives and activities, mobilize and facilitate action, and monitor progress.

- Information and analysis tools help provide a factual basis to guide policy action and monitor progress and change over time.

- Capacity building tools help enhance individuals' or organizations' existing knowledge and skills in particular areas.

- Soft infrastructure tools develop intangible connections (such as collaboration and trust or social capital) and knowledge spillovers across borders.

- Hard infrastructure tools develop tangible and physical connections (such as transport corridors, energy grids and so on) across borders.

- Mobility tools enhance movement of, for example, students, researchers, entrepreneurs and civil servants across borders, to enhance knowledge and experience and contextual understanding of different geographies.

- Research tools support cross-border research activities.

- Trade and foreign direct investment tools catalyze or enhance market interactions. 
Table A2.1 Tools for regional cooperation and integration: platform building

\begin{tabular}{|c|c|c|c|}
\hline Type of Tool & $\begin{array}{l}\text { Implemented at EU level } \\
\text { (included BSR-specific } \\
\text { instruments) }\end{array}$ & $\begin{array}{l}\text { Implemented at BSR } \\
\text { (or Nordic) level }\end{array}$ & $\begin{array}{l}\text { Implemented at } \\
\text { national level }\end{array}$ \\
\hline $\begin{array}{l}\text { Platform } \\
\text { Building }\end{array}$ & $\begin{array}{l}\text { Smart Specialization } \\
\text { Platform } \\
\text { EIB } \\
\text { EUSBSR } \\
\text { InterReg Programs } \\
\quad \text { (BSR, Central and } \\
\text { South Baltic, etc.) }\end{array}$ & $\begin{array}{l}\text { CBSS } \\
\text { BSSSC } \\
\text { NIB } \\
\text { NCM and Nordic } \\
\quad \text { Innovation } \\
\text { BDF } \\
\text { HELCOM } \\
\text { PA INNO Steering } \\
\quad \text { Committee (see } \\
\text { right) }\end{array}$ & $\begin{array}{l}\text { PA INNO } \\
\text { Steering } \\
\text { Committee (see } \\
\text { left) } \\
\text { Baltic Institute } \\
\text { of Finland } \\
\text { Swedish } \\
\text { Institute }\end{array}$ \\
\hline
\end{tabular}

Name of Tool: $\quad$ European Union Strategy for the Baltic Sea Region (EUSBSR)

Type of Tool: $\quad$ Platform Building

Implementation European Commission (Director General Regional and

Level:

Urban Policy is leading facilitation of implementation), together with member states and stakeholder organizations (as described in the EUSBSR Action Plan, chapter 'Governance of the Strategy')

Motivation and Macroregional strategies are integrated frameworks endorsed Aim: by the European Council, which may be supported by the European Structural and Investment Funds among others, to address common challenges and take advantage of common opportunities that are faced by a defined geographical area relating to member states and third countries located in the same geographical area, which thereby benefit from strengthened cooperation contributing to achievement of economic, social and territorial cohesion.

The EUSBSR was the first macroregional strategy (adopted in 2009). This was followed by the Danube Region (adopted in 2011), the Adriatic and Ionian Region (adopted in 2014), and the Alpine Region (forthcoming 2015).

Profile:

The EUSBSR was the first comprehensive EU strategy to target a macroregion and is often used as a benchmark. The eight EU countries that make up the Baltic Sea Region (Denmark, Estonia, Finland, Germany, Latvia, Lithuania, Poland and Sweden) have a long history of cooperation and face several common challenges and opportunities, reflected in the jointly agreed action plan for the strategy. Although not officially part of the strategy, Iceland and Norway are involved in implementation through the Northern Dimension framework. 
Table A2.1 (continued)

Profile:

Key features

of design and implementation:
The strategy includes a number of priority and horizontal action areas to address its three objectives: save the sea, connect the region and increase prosperity. Each of the 17 priority areas and 5 horizontal action areas is accompanied by concrete flagship projects as well as by clearly identified targets and indicators (which are reviewed and modified if needed).

The strategy (fully aligned with the Europe 2020 strategy) helps to mobilize all relevant EU, national and regional funding, and to coordinate the policies and actions of the European Union, EU countries, regions, pan-Baltic organizations, financing institutions and non-governmental bodies. The governance of the strategy includes policy, coordination and operational responsibilities. The European Level (the European Commission, European Council and High-Level Group) is responsible for setting the strategic policy framework, with increasing strategic leadership responsibilities being taken on by member states. Member states are responsible for coordinating activities and monitoring progress (through priority area coordinators, horizontal action leaders, priority area focal points and national contact points). On the operational level, member states (as well as regional organizations, NGOs, etc.) lead various flagship projects (and other contributing projects), and take on other tasks (such as facilitating generation and implementation of initiatives and projects, setting indicators and targets, reinforcing bridges to the relevant funding programs, and participating in program committees). These activities receive financing through programs and other financial instruments on European, regional and member-state levels.

$\begin{array}{cl}\text { Target } & \text { European Commission } \\ \text { groups: } & \text { Regional and national governments (line } \\ & \text { and/or sectoral ministries in particular) in } \\ & \text { participating member states } \\ & \text { Organizations (intergovernmental and non- } \\ & \text { governmental) working for collaboration across } \\ & \text { the Baltic Sea Region } \\ & \text { Implementing actors (including clusters and } \\ & \text { other business support organizations, research } \\ & \text { organizations and firms) } \\ \text { Although the strategy does not come with } \\ \text { extra EU financing, a considerable amount of } \\ \text { funding is already available to the macroregion } \\ \text { through EU regional policy, other EU programs } \\ \text { and financial instruments, various international } \\ \text { financial institutions, as well as national and } \\ \text { regional organizations. (The aim of the strategy } \\ \text { is to mobilize existing funding sources around } \\ \text { prioritized actions.) }\end{array}$


Table A2.1 (continued)

Timescale: The strategy and action plan are aligned with the Europe 2020 strategy (with deadlines for targets and indicators for 2020 and 2021). However, the action plan does not have a particular time horizon. It is a living document that is reviewed and revised according to needs.

Main results/ lessons learned:
The Commission publishes regular reports on the implementation of the EU Strategy for the Baltic Sea Region. The main results since the launch of the strategy include:

More efficient working structures around priority areas, selected in a bottom-up process of consultation - providing momentum to existing or new transnational projects (which deliver concrete results e.g. reduced pollution from ships, collaboration among fisheries, etc.);

Political leadership in priority areas taken by participating countries, regions or organizations (supported by the Commission as facilitator) - providing improved policy development frameworks (which has resulted in e.g. an integrated maritime policy, macroregional perspectives in infrastructure investments, etc.);

Improved value for money, as the macroregional approach helps align EU programs to act together on major shared goals; and

Strengthened cooperation and integration along multiple levels of government (regional, national and local).

The concept of macroregions (i.e. smaller or sub-continental groups of countries with shared contexts and challenges) and framework of the EUSBSR and action plan is a complement to EU-wide activities. With dispersed coordination and operations, macroregional activities can mobilize a broader range of stakeholders in activities.

The success of the strategy is dependent on continuous political support, commitment and ownership. The recent Commission report (May 2014) on governance of macroregional strategies highlighted the need for:

Stronger political leadership and decision making from countries and regions concerned: Ministers and national authorities coordinating the work need to take full ownership, and more clearly direct what is happening on the ground; Greater clarity in the organization of work: For authorities working on day-to-day implementation, there is a need for explicit lines of responsibility, effective coordination and sufficient resources. 
Table A2.1 (continued)

Main results/ lessons learned:
Awareness of projects and initiative results should be increased, as concrete stories of progress help to keep up momentum and broaden involvement.

Coordinated objectives and activities (through flagship projects) need to be supported by similarly coordinated funding instruments; however, it is extremely difficult to create common pots and simplified application procedures across multiple countries and multiple funding programs (with different legal bases).

It is important to focus on priorities and actions that are relevant and of strategic importance at macroregional level (i.e. those with a clear 'macroregional value added'). Actions within the strategy should not duplicate work done in other formats and frameworks.

The strategy should be an integral part of relevant national, regional and local policy frameworks. Currently, there is too much emphasis on the EU level.

\section{Name of Tool: $\quad$ Baltic Development Forum (BDF) \\ Type of Tool: $\quad$ Platform Building \\ Implementation Baltic Sea Region \\ Level:}

Motivation and The Baltic Development Forum (BDF) was founded in November

Aim: 1998 by Uffe Ellemann-Jensen (former Danish foreign minister). The BDF was established in light of a perceived need for a platform for decision makers to discuss joint public-private strategies for the development of the Baltic Sea Region. BDF is the only BSR organization that gathers not only politicians, but also business, academia and media. The mission of BDF is to position the Baltic Sea Region in the EU and on the global map by advancing the growth and competitive potential through partnership between business, government and academia.

Profile: decision makers from business, politics, academia and media in the Baltic Sea Region (situated in Copenhagen, Denmark). The BDF fulfills its mission by acting as a catalyst, facilitator and developer of concrete projects and strategies; providing a platform for all interested regional stakeholders; and influencing and shaping the regional policy agenda of tomorrow.

BDF differentiates itself from other organizations and institutions promoting regional integration and cooperation in the BSR with its focus on and involvement of the business community.

Main activities include publishing thematic analyses and flagship reports (including State of the Region and Political State of the Region); and facilitation of numerous projects, task forces and knowledge platforms. BDF also has a formal role within the EU 
Table A2.1 (continued)

Profile:

Key features

of design and

implementation: strategy for the Baltic Sea Region as Horizontal Action Leader. Every year, BDF organizes a high-level summit in one of the Baltic Sea countries, and BDF currently organizes thematic conferences, round tables etc. on topics related to growth and competitiveness in the Region.

The BDF focuses on three thematic areas: digital economy, smart sustainable growth, and competitiveness. The main activities are in information and communication technology, water and blue growth, energy, smart cities, and promotion and investment.

The BDF is an independent, non-profit organization. BDF's activities are implemented by an international staff, led by Director Flemming Stender. The overall strategy and activities are set by the BDF Board, chaired by Lene Espersen (former foreign minister and minister for business), honorary and advisory boards (consisting of people from all parts of the Baltic Sea Region that possess strong competences, experience and knowledge), as well as strategic partners and partners who also provide input to the strategic direction of the organization.

The BDF is supported by a broad variety of partners that contribute and enable the work and activities carried out by the Baltic Development Forum. Partners are both public and private actors with a profound interest in contributing to the Baltic Sea Regional Agenda. In addition, BDF works with various partners, and has close collaborations with other networks and organizations at the Baltic Sea Regional, European and global level.

Target groups: Business

Government

Academia

Media

NGOs

Level of The BDF Secretariat is funded by partners and financial members and through project and networking support: activities.

Timescale: Established as a permanent institution

Main results/

The work of the BDF has resulted in a number of main

lessons learned: achievements over the last 16 years, including the organization of 16 annual summits; the publication of 11 State of the Region Reports and numerous thematic reports; and the facilitation of many projects, conferences and knowledge platforms.

In 2014, BDF launched a new regional ICT think tank 'Top of Digital Europe' to promote the Baltic Sea Region as one of the leading digital regions in the world. Also, BDF is coordinator 
Table A2.1 (continued)

Main results/ lessons learned: for the Fehmarn Belt Days 2014 and is involved in activities related to the emerging Fehmarn Belt Region. Furthermore, BDF strengthened its capacity in the area of water and environment, publishing a report on corporate water stewardship and facilitating dialogue on marine and maritime issues.

BDF is viewed as a neutral platform ('honest broker') for catalyzing and facilitating cooperation all over the region.

A strong network developed over many years among business, government and others regional stakeholders is important to the creation of public-private partnerships in various areas.

Close collaboration and involvement of the business community is imperative to drive action in prioritized areas.

The focus on and prioritization of regional integration and collaboration can vary over time for both political and business stakeholders. It is important to have a core group of strategic partners across the macroregion to be able to adjust to trends.
Name of Tool: $\quad$ Priority Area Innovation (PA INNO) Steering Committee

Type of Tool: Platform Building

Implementation Level:

Motivation and Aim:

Profile:

\section{Baltic Sea Region and National (in collaboration)}

As part of the EU Strategy for the Baltic Sea Region (EUSBSR) and Action Plan, 17 priority areas and 5 horizontal action areas have been established to fulfill the three overall objectives (save the sea, connect the region, and increase prosperity). The Priority Area of Innovation (PA INNO) is one of the priority areas that contribute to the objective of 'increasing prosperity'. PA INNO has four overall aims:

1. to enhance coherence and collaboration of $R \& D$ and innovation activities in the Baltic Sea Region;

2. to establish a common BSR innovation strategy;

3. to develop the fifth freedom (free movement of researchers, knowledge and technology);

4. to be recognized as a leading knowledge and innovation region in the world.

The Priority Area is led by a coordinator (PAC) and each priority area has a Steering Group. The PA INNO Steering Group is charged with setting the overall strategic goals, targets and indicators for this priority area, as well as monitoring progress towards achieving these goals. Progress is achieved through the work of the six flagship projects within PA INNO: BSR Stars, BSR Fund, Health Port, Science Link, Baltic Ring and Submariner.

The PA INNO Steering Group is one of the governance structures of the EUSBSR - charged with setting the strategic goals (including targets and indicators) of the priority area, as well as 
Table A2.1 (continued)

Profile:

Key features

of design and implementation: monitoring progress towards these goals (through coordination of the six flagship projects included in PA INNO and development of new projects).

The PA INNO Steering Group is made up of representatives from ministries and implementing agencies with a mandate for innovation policy in each of the 10 Baltic Sea Region countries (the 8 EU member states, plus Iceland and Norway). Representatives are primarily from national-level government; however, regional-level governments are also represented. In addition to governmental representatives, the PA INNO Steering Group includes representatives from each of the Flagship Projects.

The PA INNO Steering Group was established in early 2014. Prior to this, the group existed as a 'high-level group' guiding implementation of one of the flagship projects within PA INNO (BSR Stars). The PA INNO Steering Group meets three to four times a year.

The organization and implementation of the meetings, as well as the time spent developing strategic frames, targets and indicators, is financed primarily by funding and in-kind contributions from participating ministries and agencies (on national and regional levels). Some financial support has been provided through BSR program-funded projects. (All flagship projects and other activities to achieve the goals of PA INNO are funded separately.)

Target groups: Ministries and innovation agencies (on national and regional levels) in the Baltic Sea Region

European Commission

Leaders of flagship projects (and other projects contributing to realizing the goals of the PA

Level of financial There is no established budget for the PA INNO support: Steering Group. Time and expenses are covered by participating ministries and innovation agencies.

Timescale: $\quad$ PA INNO (and other priority areas) follow the EUSBSR, which has a time horizon of 2020. The action plan is reviewed and adjusted regularly, according to needs.
Main results/ lessons learned:
The priority area has achieved a number of results including establishing targets and indicators, providing input and guidance to the BSR Program (and EU InterReg fund), and strengthening the strategic policy-level network in the BSR. Flagship projects within the priority area have contributed to additional concrete results (e.g. engaging small companies in transnational activities, developing prototypes, etc.). 
Table A2.1 (continued)

Main results/ lessons learned:
The ambitions and success of the Priority Area are very dependent on the anchoring and drive coming from the members of Steering Group, and the commitment of each of their organizations.

Without strong backing from participating member states (including allocation of human and financial resources), the Steering Group and the activities it coordinates would not move forward.

The heterogeneity of experience and capacity that exists among the member states requires that certain countries take stronger leadership responsibilities. At all levels of governance, a strong and inspirational core leadership (comprised of at least 2 countries) is key.

Management and implementation of specific tasks should be distributed among a broader range of stakeholders (to ensure ownership and engagement).

Having a mandate but no accompanying budget is a challenge, requiring close collaboration with funding programs (such as the EU's interregional funds).

The development of transnational partnerships - gathering complementary competencies from different places - to address common societal issues is an asset. However, getting each partner to work as a transnational team (prioritizing joint goals) is a challenge.

Strengthening cooperation and integration on the innovation policy level is also a challenge, as individual organizations still have their own 'home' mandates as the main guide. It will probably take at least 5-10 years before any larger effects are seen from this coordinated transnational policy work.

Notes: $\quad \mathrm{BDF}=$ Baltic Development Forum; BSSSC $=$ Baltic Sea States Subregional Co-operation; CBSS = Council of Baltic Sea States; EIB = European Investment Bank; EUSBSR $=$ European Union Strategy for the Baltic Sea Region; HALs $=$ Horizontal Action Leaders; HELCOM = Baltic Marine Environment Protection Commission; ICT = Information and communication technology; InterReg = interregional; $\mathrm{NCM}=$ Nordic Council of Ministers; $\mathrm{NGO}=$ non-governmental organization; $\mathrm{NIB}=$ Nordic Investment Bank; PACs = priority area coordinators; PA INNO = Priority Area Innovation; $\mathrm{R} \& \mathrm{D}$ = research and development.

Source: Author.

The next two tools are examples of information and analysis (both implemented at EU level) that help provide a factual basis to guide policy action, and monitor progress and change over time. 
Table A2.2 Tools for regional cooperation and integration: information and analysis

\begin{tabular}{l|ll|l|l}
\hline Type of Tool & $\begin{array}{l}\text { Implemented at EU } \\
\text { level (included BSR- } \\
\text { specific instruments) }\end{array}$ & $\begin{array}{l}\text { Implemented at BSR (or } \\
\text { Nordic) level }\end{array}$ & $\begin{array}{l}\text { Implemented } \\
\text { at national } \\
\text { level }\end{array}$ \\
\hline $\begin{array}{l}\text { Information and } \\
\text { Analysis }\end{array}$ & $\bullet \begin{array}{l}\text { EU Innovation } \\
\text { Scoreboard } \\
\text { European Cluster } \\
\text { Observatory } \\
\text { European Cluster } \\
\text { Collaboration } \\
\text { Platform }\end{array}$ & $\bullet \begin{array}{l}\text { State of the Region } \\
\text { Report } \\
\text { ESPR Innovation } \\
\text { Monitor }\end{array}$ & \\
\hline
\end{tabular}

Name of Tool: $\quad$ European Observation Network for Territorial Development and Cohesion (ESPON)

Type of Tool: Information and analysis

Implementation European Commission (Directorate General Regional

Level: and Urban Policy); ESPON is a program within EU Cohesion Policy

Motivation and

The first program for European Observation

Aim:

Network for Territorial Development and

Cohesion (ESPON 2006) was established as a

result of ministerial discussions about European

Spatial Development (see European Spatial

Development Perspective from May 1999). The

discussions proposed strengthened support to

transnational activities under InterReg as well

as testing the idea of a European Observatory

on Territorial development. At the end of the

period, the ESPON 2006 program was continued,

establishing the ESPON 2013 Program. An

ESPON 2020 Cooperation Program is currently

under consultation, becoming a third generation

of ESPON.

The proposed mission of ESPON 2020 is: 'ESPON

2020 shall continue the consolidation of a

European Territorial Observatory Network and grow the provision and policy use of pan-

European, comparable, systematic, and reliable territorial evidence.' Building on this overall mission statement, the draft Cooperation Program sets out five specific objectives for activities during 2014-2020 to: (1) produce territorial evidence through applied research; (2) upgrade knowledge transfer and support to users in targeted analyses and policy briefs and working papers; (3) improve territorial observation of Europe and tools for 
Table A2.2 (continued)

Motivation and Aim:

Profile: analyses; (4) widen outreach and uptake of territorial analyses; and (5) deliver a more streamlined administrative structure to promptly inform policy processes.

ESPON supports EU Cohesion Policy by providing evidence on territorial developments on a large number of relevant themes as well as useful tools and analyses, to support the most efficient spending of funds (on both EU and member state levels).

The ESPON 2013 Program covers the entire territory of the European Union (EU) plus Iceland, Liechtenstein, Norway and Switzerland, and includes the following operational areas:

- Applied research on themes of European territorial dynamics, providing scientifically solid facts and evidence at the level of regions and cities. The applied research is conducted by transnational groups of researchers and experts.

- Targeted analyses developed upon stakeholders' requests and conducted together with them.

- Scientific platform development is supported by an ESPON database, actions dealing with territorial indicators and monitoring, as well as tools related to territorial analyses, typologies, modeling and updates of statistics. This operational area has included a project on 'Territorial Monitoring of the Baltic Sea Region', led by NordRegio.

- Capitalization of ESPON results that includes media activities and different ESPON publications, transnational networking activities, and events (such as ESPON seminars and workshops, organized in collaboration with a network of national ESPON Contact Points).

- Technical assistance, analytical support and communication ensure the sound management of the program and the ability of processing scientific output towards the policy level.

ESPON uses an open competitive process in the selection of projects, which shall include a partnership involving at least three countries. Calls have been launched regularly.

The ESPON Coordination Unit (located in Luxembourg) acts as the secretariat for the ESPON 2013 Program. It provides technical support for the monitoring committee, the certifying authority and the audit authority in relation to the management of 
Table A2.2 (continued)

Profile:

Data covered and data sources: the program. In addition, due to the specific nature of the ESPON 2013 Program, the coordination unit also performs analytical tasks, processing the research results and feeding territorial evidence into the policy arena to ensure the achievement of the objectives and mission of the program. The renewal envisaged for the ESPON 2020 Program includes the creation of an ESPON EGTC (replacing the coordination unit), which will be contracted to carry out all content-related actions. This new setting is also decided to provide for a leaner administrative burden.

The ESPON 2013 database provides fundamental regional information provided by ESPON projects and EUROSTAT. This information can be used to support territorial development analysis at different geographical levels. The database aims to contribute to a better understanding of the potentials and development perspectives of regions in the European context and globalized world as its comparable data makes benchmarking of regions and cities feasible.

The ESPON 2013 database provides access to the following data categories: regional, local, urban, neighborhood (candidate countries), world, grid and historical data. Most of the datasets and information produced are publicly available and freely accessible. The datasets and indicators are related to economy, finance and trade; population and living conditions; labor market; education; health and safety; information society; agriculture and fisheries; transport and accessibility; environment and energy; science and technology; governance and territorial structure.

The data and indicators cover the entire European Union plus Iceland and Liechtenstein, Norway and Switzerland (ESPON space). The regional and local data and indicators use the Nomenclature of Territorial Units for Statistics references. The other types of data use similar statistical units or grid. Moreover, the ESPON database is documented by technical reports describing the main topics addressed during the implementation of the ESPON 2013 database supporting the understanding of the data categories available. Most of these technical reports are public and freely accessible on the ESPON website.

The search interface allows the user to search for relevant data and indicators via themes, policy aspects, projects 


\section{Table A2.2 (continued)}

Data covered and data sources:

Key features of design and implementation:

or keywords. The search results can be further filtered using 'where' and 'when' filters. Metadata on the data and indicators can be viewed and the data itself can be downloaded. The search interface gives access to regional data and metadata collected or produced in the framework of ESPON projects.

Target groups:

Level of financial support:

Timescale:
- Public authorities (on national, regional and local levels) in EU member states, plus Iceland, Liechtenstein, Norway and Switzerland

- Program authorities on European level

- Research groups focused on territorial development The ESPON 2020 program is envisaged to be co-financed by the European Regional Development Fund (ERDF) with an amount of $€ 41.3$ million ( $\$ 44.6$ million). Member and partner states are envisaged to add their financial contribution, making a total budget of slightly above $€ 50$ million (\$54 million) for the 2014-20 period.

The ESPON Program coincides with European programming periods (and is currently under preparation for the 2014-20 period).
Main results/ lessons learned:
- Key results from the ESPON program over the past 15 years include: structured data on territorial developments for evidence-based policy making, strengthened networks among both researchers and policy makers working on territorial development and cohesion policy, as well as the development of targeted analyses, tools and methodologies.

- The recent consultation prior to the elaboration of an ESPON 2020 Program highlighted a number of needs for the coming period: 
Table A2.2 (continued)

Main results/ lessons learned:
- more specific identification of target groups;

- a focus on future-orientated approaches and forecasting territorial impacts;

- greater emphasis on cross-border, mountain and peripheral rural regions;

- $\quad$ stronger scientific quality of results;

- a greater focus on governance and policy implementation;

- a more systematic application of territorial impact assessments across all EU programs; and

- stronger cooperation with local and regional authorities.

- Outreach, communication and capitalization of output are the greatest challenges.

- The recent consultation also highlighted suggestions for improving the role of territorial evidence in informing policy, including:

- ESPON evidence needs to be in sync with political processes and not merely academic exercises.

- A more user-friendly and interactive website, and simplified communication strategies such as videos, social media, short messages, newsletters should be developed.

- There should be more use of seminars, workshops and conferences, including at the local level.

- Researchers and policy makers should foster a closer partnership.

- Additional lessons learned regarding the storage, management and query of different types of regional data are related to acknowledging the different characters of data, i.e. core data and data resulting from ESPON projects, and developing most suitable approaches for both; the use of web services to make data accessible not only to other people but also computer programs; and continuing to explore new frontiers for data collection and innovative territorial approaches in support of evidence-based policy making. 
Table A2.2 (continued)

Main results/ lessons learned:
- The next ESPON 2020 Cooperation Program will represent a renewal and upgrade of ESPON including a new institutional setting and take-up of the challenges mentioned above.

Notes: $\quad$ BSR $=$ Baltic Sea Region; ESPON $=$ European Observation Network for Territorial Development and Cohesion; ERDF = European Regional Development Fund; EGTC = European Grouping for Territorial Cooperation; EU = European Union; EUROSTAT $=$ European statistics; InterReg $=$ interregional.

Source: Author.

Table A2.3 Tools for regional cooperation and integration: capacity building

\begin{tabular}{|c|c|c|c|}
\hline Type of Tool & $\begin{array}{l}\text { Implemented at EU } \\
\text { level (included BSR- } \\
\text { specific instruments) }\end{array}$ & $\begin{array}{l}\text { Implemented } \\
\text { at BSR (or } \\
\text { Nordic) level }\end{array}$ & $\begin{array}{l}\text { Implemented at } \\
\text { national level }\end{array}$ \\
\hline Capacity Building & $\begin{array}{l}\text { - Administrative } \\
\text { Capacity } \\
\text { Building } \\
\text { (Directorate } \\
\text { General for } \\
\text { Regional } \\
\text { Policy) } \\
\text { European } \\
\text { Cluster } \\
\text { Excellence } \\
\text { Initiative }\end{array}$ & & $\begin{array}{l}\text { - } \text { Swedish } \\
\text { Institute } \\
\text { (Baltic) } \\
\text { Leadership } \\
\text { Program }\end{array}$ \\
\hline
\end{tabular}

Name of Tool:

Type of Tool:

Implementation Level: European Commission (a project funded under the responsibility of Directorate-General for Internal Market, Industry, Entrepreneurship and SMEs Unit for SMEs: Clusters and Emerging Industries)

Motivation and Aim: The European Cluster Excellence Initiative (ECEI) aimed to develop skills for managing cluster initiatives. The project developed a set of cluster quality indicators and a quality label for professional cluster management, as well as knowledge and training materials. These efforts contribute to 
Table A2.3 (continued)

Motivation and Aim: stronger professionalism and increased capacity of cluster management (an example of soft innovation infrastructure). This, in turn, is aimed at contributing to strengthened firm-level productivity.

Profile:

The ECEI was a European-funded project running for 3 years (from 1 September 2009 to 31 August 2012). The ECEI (see www.cluster-excellence. eu) put together a consortium of experienced persons and organizations to identify and put into place a set of quality indicators and peerassessment procedures for cluster management. The aim was to develop training materials and set up an approach for quality labeling of cluster management, to help cluster managers achieve high levels of excellence in their duties and to succeed in the peer assessments. At the completion of the project, the services (including cluster management benchmarking, training and networking) have been set up on a self-sustaining basis.

Quality indicators and peer-assessment procedures for cluster management, and cluster organization labeling activities are continually developed and implemented through the European Secretariat for Cluster Analysis (see www.cluster-analysis. org). The Foundation for Clusters Excellence offers courses for trainers of cluster management excellence based on the ECEI curriculum, and administers the ECEI training materials (see www.clustercompetitiveness. org). The European Cluster Group (ECG) is the organizational structure for the future of the European Cluster Managers' Club, with strong cooperation links to the TCI Network. International cluster-to-cluster networking is facilitated through the European Cluster Collaboration Platform (see www. clustercollaboration.eu).

The European Commission has validated and applied the benchmarking tool and the training materials developed within the ECEI through eight projects funded from two calls for proposals (targeting officials working 
Table A2.3 (continued)

Profile:

Key features of design and implementation:

in regional or national public organizations managing cluster activities). In the spring of 2014, the European Commission launched a new call for proposals targeting consortia of cluster organizations and business networks. This call was the first action in the framework of the Cluster Excellence Program supported under the Competitiveness of Small and Medium-sized Enterprises Program (under Directorate General Enterprise and Industry). The aim of the call was to pursue EU efforts to strengthen cluster management excellence in the EU as a way to provide more professional business services to European SMEs through clusters and therefore contribute to the development of more world-class clusters in the EU.

Target groups:
- Cluster managers in the European Union (as well as associated and neighboring countries)

- Policy makers (particularly those working with implementation of cluster programs at regional or national levels)

- Educators (who are involved in developing and disseminating knowledge and teaching cases)

Level of The EU investments in cluster excellence financial activities (including the initial ECEI support: project and the projects validating and applying results) in the previous programming period (2007-13) totaled $€ 3.3$ million (\$3.6 million). The total budget for EU investments in cluster excellence activities in the current programming period is $€ 7$ million ( $\$ 7.6$ million).

Timescale: The initiating ECEI project had a 3-year duration. Current actions to strengthen cluster management excellence are pursued within the Cluster Excellence Program under Competitiveness of Small and Medium-sized Enterprises, which will last through the current programming period (2014-20). 
Table A2.3 (continued)

Main results/lessons learned:
- The ECEI project (and follow-on projects) have contributed to the following results:

- the development of quality indicators and peer-review assessment procedures for cluster management;

- the development of a curriculum and casebased teaching materials for cluster managers and officials working in regional and national organizations managing cluster activities;

- the benchmarking and labeling of more than 570 cluster organizations from 36 countries; and

- the training of 40 cluster instructors on how to improve the individual management skills of cluster managers.

- Although SMEs are considered as crucial engines for growth and job creation, their competitiveness is affected by a limited exploitation of international opportunities and innovation prospects in the single market and beyond. Clusters are viewed as relevant vehicles to catalyze and support SMEs (and other firms) in fostering internationalization and innovation efforts. It is thus viewed as important to support the quality of cluster management and business support services that clusters provide.

- Investments in cluster excellence not only build capacity of cluster management, but also facilitate linkages and increased cooperation between clusters. The labels provide legitimacy and evidence of clusters that have similar levels of management practice and quality.

- With a structured framework of quality indicators and benchmarking activities, there is an incentive for continuous improvement. Cluster managers have a clearer grasp on areas of improvement. One of the challenges for the future is finding ways to leverage existing European tools (benchmarking and training) in a more integrated fashion (i.e. areas of improvement identified through analysis leads into development and 
Table A2.3 (continued)

Main results/lessons learned: implementation of new training modules) to support continuous capacity-building in clusters.

- The EU level can provide support to develop uniform frameworks (e.g. quality indicators and training materials) and platforms to disseminate and continually develop knowledge and build capacity in this area. But EU-level investments (through the competitiveness of small- and medium-sized enterprises) are not enough. These efforts need to be complemented by additional efforts on regional and national level.

Notes: $\quad$ BSR $=$ Baltic Sea Region; ECEI = European Cluster Excellence Initiative; ECG = European Cluster Group; EU = European Union; SMEs = small- and mediumsized enterprises; TCI $=$ The Competitiveness Institute.

Source: Author.

Table A2.4 Tools for regional cooperation and integration: mobility

\begin{tabular}{l|l|l|l}
\hline Type of Tool & $\begin{array}{l}\text { Implemented } \\
\text { at EU level } \\
\text { (included } \\
\text { BSR-specific } \\
\text { instruments) }\end{array}$ & $\begin{array}{l}\text { Implemented at BSR } \\
\text { (or Nordic) level }\end{array}$ & $\begin{array}{l}\text { Implemented at } \\
\text { national level }\end{array}$ \\
\hline Mobility & $\bullet \begin{array}{l}\text { ERASMUS } \\
\text { Marie } \\
\text { Curie }\end{array}$ & $\bullet \begin{array}{l}\text { Baltic University } \\
\text { Program } \\
\text { Nordic Mobility } \\
\text { Program }\end{array}$ & $\begin{array}{l}\text { National } \\
\text { programs for } \\
\text { researcher } \\
\text { and student } \\
\text { mobility }\end{array}$ \\
\hline
\end{tabular}

Name of Tool: Baltic University Program (BUP)

Type of Tool: Mobility

Implementation Baltic Sea Region

Level:

Motivation and Prompted by the historic changes taking place in the region Aim: and recognizing the central role that universities play in societal development, the Baltic University Program (BUP) was established in 1991 with the intention of contributing 
Table A2.4 (continued)

Motivation and

Aim:

Profile: to development of the Baltic Sea Region by strengthening international cooperation between East and West. The BUP was established as a network of universities in the BSR aimed at developing novel ways to strengthen interaction among universities and between universities and society, with a focus on sustainable regional development.

The BUP is a network of about 225 universities and other institutes of higher learning located in 14 countries around the Baltic Sea Region. It is coordinated by the Baltic University Program Secretariat (under the leadership of a Program Director), established as a unit at Uppsala Centre for Sustainable Development (CSD Uppsala) at Uppsala University, under the governance of an international board.

The program focuses on questions of sustainable development, environmental protection, and democracy in the Baltic Sea Region. The aim is to support the key role that universities play in a democratic, peaceful and sustainable development. This is achieved by developing university courses, and by participation in projects in cooperation with authorities, municipalities and others. The Program plans, produces and coordinates undergraduate and master's-level courses (on topics such as environmental science, Baltic Sea Region history and regional development, water management and environmental management) and runs joint research projects. The chosen subjects are of common concern for the entire region, and international cooperation is of key importance. The activities concentrate on different aspects of sustainable development in the region. At present almost 10000 students participate in the program each year.

The program is funded by a number of national and multinational sources, including: the Swedish Government and Uppsala University, the Swedish Institute, the Baltic Sea Unit of SIDA, Finnish funds, the Nordic Council of Ministers, and some EU programs. In addition, the participating universities contribute to the program. 
Table A2.4 (continued)

Profile:

The participating universities include classical universities, as well as universities of technology, agriculture, culture economics, pedagogics etc. All countries within or partly, within the Baltic Sea drainage basin are represented:

Belarus, Denmark, Estonia, Finland, Germany, Latvia, Lithuania, Poland, the Russian Federation and Sweden, and, more marginally, the Czech Republic, Norway, Slovakia and Ukraine. A large network of researchers and teachers at the universities has developed.

The role of the BUP Secretariat is to support and promote regional cooperation and contacts between the universities and corresponding institutions of higher learning in the Baltic Sea Region. The secretariat administers the economy of the program, including contacts with funding organizations. The production of courses and course material, including books and film series, are organized from the secretariat in cooperation with the national centers and individual teachers and researchers in the network. The Baltic University Program is one of the flagships within PA Education (of the EUSBSR).

$\begin{array}{lll}\begin{array}{l}\text { Key features } \\ \text { of design and } \\ \text { implementation: }\end{array} & \begin{array}{c}\text { Target } \\ \text { groups: }\end{array} & \begin{array}{l}\text { - University students in the BSR } \\ \text { University professors and educators in the }\end{array} \\ & \begin{array}{r}\text { Level of } \\ \text { financial } \\ \text { support: }\end{array} & \begin{array}{l}\text { The annual budget for the BUP Secretariat } \\ \text { is approximately } € 550000 \text { (\$594000) } \\ \text { (funded by national and multinational } \\ \text { sources, and member universities). In } \\ \text { addition, the BUP gets separate } \\ \text { financial support for research and applied } \\ \text { projects. } \\ \text { Established as a program at Uppsala } \\ \text { University }\end{array} \\ & \end{array}$

Main results/ lessons learned:
- The work of the BUP has resulted in a number of main achievements over the last 23 years, including the transnational development of four bachelor-level and seven master's-level courses, the transnational publication of several books and other material, the mobility of about 250 students (annually) in educational programs and other activities (e.g. conferences, student Parliament and summer sailing). 
Table A2.4 (continued)

Main results/ lessons learned:
- It is effective to start with a concrete joint activity (such as developing joint courses) with additional activities (such as joint research and applied projects) developing out of this.

- The financing of student mobility (through e.g. ERASMUS) is a useful complement to joint university programs.

- Recent interest is focused on mobility at the PhDlevel, avoiding the administrative obstacles faced at the undergraduate level.

- One basic idea of the BUP is to foster international and intercultural understanding among students, which is done by gathering multinational student groups together to work and learn together in courses and conferences (in contrast to a one-to-one exchange).

Notes: $\quad$ BSR $=$ Baltic Sea Region; BUP $=$ Baltic University Program $;$ CSD Uppsala $=$

Uppsala Centre for Sustainable Development; ERASMUS = European Community Action Scheme for the Mobility of University Students; EU = European Union; EUSBSR = European Union Strategy in the Baltic Sea Region; $\mathrm{PA}=$ priority area; $\mathrm{PhD}=$ doctor of philosophy; SIDA = Swedish International Development Cooperation.

Source: Author.

Table A2.5 Tools for regional cooperation and integration: research

\begin{tabular}{l|l|l|l}
\hline Type of Tool & $\begin{array}{l}\text { Implemented at } \\
\text { EU level (included } \\
\text { BSR-specific } \\
\text { instruments) }\end{array}$ & $\begin{array}{l}\text { Implemented } \\
\text { at BSR (or } \\
\text { Nordic) level }\end{array}$ & $\begin{array}{l}\text { Implemented at } \\
\text { national level }\end{array}$ \\
\hline Research & $\bullet$ Horizon 2020 & $\bullet \begin{array}{l}\text { BONUS } \\
\text { program }\end{array}$ & $\begin{array}{l}\text { Bilateral } \\
\text { programs } \\
\text { between SE/ } \\
\text { VINNOVA } \\
\text { and FI/Tekes, } \\
\text { etc. }\end{array}$ \\
\hline $\begin{array}{l}\text { Name of Tool: } \\
\text { Type of Tool: }\end{array}$ & $\begin{array}{l}\text { BONUS } \\
\text { Research and innovation }\end{array}$ \\
Level: & Baltic Sea Region & \\
\hline
\end{tabular}


Table A2.5 (continued)

Motivation and

Aim:

Profile:
Building on experience from previous transnational research activities (in e.g. ERA-NET and BONUS+ programs), and following the adoption of the EU Strategy for the BSR in 2009, the European Parliament and Council decided on the participation of the Union in a Joint Baltic Sea Research and Development Program (BONUS) undertaken by several member states (Decision No. 862/2010/EU). BONUS aims to combine research and innovation related to the Baltic Sea ecosystem into a joint and durable interdisciplinary and focused multinational program that supports the Baltic Sea Region's sustainable development, and produces knowledge and technological solutions to support the development and implementation of regulations, policies and management practices tailored for the Baltic Sea Region.

BONUS is a policy-driven research and development program that supports the sustainable development and ecosystem-based management of the Baltic Sea Region, the HELCOM Baltic Sea Action Plan, and the EU Marine Strategy Framework Directive (as well as other European, regional and national coastal and marine environmental policies and plans).

The BONUS program and its strategic research agenda has been developed together with over 800 stakeholders across the region. The program is dynamic and flexible, and takes into account future demands during its regular updates, most recently published in early 2014 . The five strategic objectives deal with ecosystem, coast and catchment area, marine goods and services, societal responses, and observation and data management in the Baltic Sea Region.

BONUS is one of five existing programs under Article 185 (defined by the EU treaty). These programs are jointly funded by the member states $(50 \%)$ and the European Commission $(50 \%)$. BONUS is supported by a total of $€ 100$ million (\$108 million) for the years 2011-17. BONUS members are the national research funding institutions in the eight EU member states around the Baltic Sea (Denmark, Estonia, Finland, Germany, Latvia, Lithuania, Poland and Sweden) who fund BONUS jointly with the EU's Seventh Program for research, technological development and demonstration. 
Table A2.5 (continued)

Profile:

Key features of design and implementation:
In addition, call-specific funders support BONUS calls. The Russian Federation participates in BONUS through bilateral agreements.

BONUS issues calls for competitive proposals and funds projects of high excellence and relevance based on its strategic research agenda. BONUS facilitates researchers' collaboration, networking, human capacity-building, and joint use of research infrastructures.

\begin{tabular}{|c|c|}
\hline $\begin{array}{l}\text { Target } \\
\text { groups: }\end{array}$ & $\begin{array}{l}\text { - Researchers (from academia and } \\
\text { industry) in the eight BSR member } \\
\text { states } \\
\text { - Companies in the eight BSR member } \\
\text { states } \\
\text { Other organizations participating in } \\
\text { research and innovation activities in the } \\
\text { eight BSR member states } \\
\text { - Decision makers and other end-users of } \\
\text { the knowledge and innovation generated } \\
\text { within the program }\end{array}$ \\
\hline $\begin{array}{l}\text { Level of } \\
\text { financial } \\
\text { support: }\end{array}$ & $\begin{array}{l}€ 100 \text { million of funding is available over } \\
7 \text { years }(2011-17)\end{array}$ \\
\hline Timescale: & 7 years $(2011-17)$ \\
\hline
\end{tabular}

Main results/

- Since its establishment in 2010, the BONUS program lessons learned: has strengthened collaboration among national funding institutions, launched 3 calls for proposals, from which 15 collaborative research and 13 collaborative innovation projects are or will be funded (for a total of approximately $€ 48$ million ( $\$ 52$ million)), and engaged over 100 research institutes and universities in 9 Baltic Sea countries. At least one more call will be launched in 2015.

- It has been a challenge to bring together actors across sectoral borders. BONUS collaboration has brought not only scientists but more importantly the science policy makers and funders around the same table (covering the areas of environmental, transportation, agriculture, energy, employment, economy and other policy areas).

- Expanding on experience with calls for joint research projects, BONUS has worked together with BSR Stars (see profile description below) to develop and launch 
Table A2.5 (continued)

Main results/ lessons learned: calls for innovation projects. It has been an enlightening experience to work with innovation agencies in the BSR - adjusting call texts and selection criteria to attract company participation ensuring a focus on innovation.

- BONUS has succeeded in tailoring the program according to the priorities of 8 countries and adjusting the program to research and innovation projects. BONUS is a truly multinational program, as all participating countries are involved in each call. BONUS has developed a mechanism for combining national and EU funding, and applying common funding rules regardless of the source of the funds. BONUS has developed good relationships with relevant end-users and other stakeholders, which ensures a wide exploitation of the program's outputs as well as wide participation in the program planning.

Notes: $\quad$ BONUS $=$ Joint Baltic Sea Research and Development Program; BSR $=$ Baltic Sea Region; ERA-NET = European Research Area Network; EU = European Union; $\mathrm{FI}=$ Finland $\mathrm{SE}=$ Sweden .

Source: Author.

Table A2.6 Tools for regional cooperation and integration: soft infrastructure

\begin{tabular}{l|l|l|l}
\hline Type of Tool & $\begin{array}{l}\text { Implemented } \\
\text { at EU level } \\
\text { (included } \\
\text { BSR-specific } \\
\text { instruments) }\end{array}$ & $\begin{array}{l}\text { Implemented at } \\
\text { BSR (or Nordic) } \\
\text { level }\end{array}$ & $\begin{array}{l}\text { Implemented at } \\
\text { national level }\end{array}$ \\
\hline $\begin{array}{l}\text { Integration (soft } \\
\begin{array}{l}\text { infrastructure, } \\
\text { focused on } \\
\text { clusters) }\end{array}\end{array}$ & $\begin{array}{l}\text { European } \\
\text { Strategic } \\
\text { Cluster } \\
\text { Partnerships }\end{array}$ & $\bullet \begin{array}{l}\text { BSR Stars } \\
\text { program } \\
\text { Scanbalt } \\
\text { network }\end{array}$ & $\begin{array}{l}\text { Norwegian } \\
\text { Innovation } \\
\text { Clusters }\end{array}$ \\
\hline
\end{tabular}


Table A2.6 (continued)

Name of Tool: $\quad$ BSR Stars Flagship Program

Type of Tool: $\quad$ Integration - soft infrastructure

Implementation Baltic Sea Region (under PA INNO of EUSBSR) and

Level: national

Motivation and The aim of BSR Stars is to strengthen competitiveness and

Aim:

Profile: economic growth in the Baltic Sea Region. This will be achieved by fostering transnational linkages between specialized research and innovation nodes, leading to new types of collaboration that can deliver new products, services and business models for global markets.

BSR Stars is a flagship within the priority area of innovation of the EU Strategy for the BSR (see previous profile descriptions of both EUSBSR and PA INNO). The BSR Stars flagship was designed in connection with the adoption of the EUSBSR (and accompanying action plan) in 2009-10, building on national experience with innovation policies and cluster programs and previous collaboration activities in the area of cluster policy in the region. The program design was, in itself, a collaborative effort, involving 40 people from 10 countries' ministries and national innovation agencies. The countries involved are: Denmark, Estonia, Finland, Germany, Iceland, Latvia, Lithuania, Norway, Poland and Sweden.

The mission of BSR Stars is to shape a more integrated and dynamic resource base by linking strong research environments, clusters and SME-networks, creating a number of globally leading research and innovation hubs in the BSR to achieve stronger critical mass, attractiveness, and a competitive international position. These hubs (or transnational innovation partnerships) will be skilled in identifying market potentials in 'grand challenges', mobilizing competencies that may be dispersed over different sectors and geographies, and providing open platforms from which various actors can work together to create innovative solutions that tackle these challenges.

The BSR Stars program is a long-term initiative working toward four overall objectives:

1. Facilitating transnational networks, partnerships and strategic alliances between cluster organizations, companies, universities and public authorities, which lead to:

- new collaborative business models, commercialized applications, products and services; 
Table A2.6 (continued)

Profile:

- increased export activities (both between countries within the BSR and outside of the BSR); and - new firms and jobs

2. Sharing, developing and utilizing open and demanddriven innovation methods

3. Improving innovation policy capabilities to leverage specialized national strongholds - bringing added value to all involved (i.e. macroregional smart specialization)

4. Strengthening the international visibility and attractiveness of the BSR's innovation capabilities

These objectives have been addressed through the continued development of the innovation policy framework (via the PA INNO Steering Committee), implementation of the StarDust project (2010-2013) - including facilitation of five transnational innovation partnerships, implementation of annual cluster-to-cluster matchmaking events (in 2013 and 2014), and joint development and implementation of two transnational calls for proposals (BSR Innovation Express and BONUS Innovation calls).

BSR Stars is governed by a 'high-level group' of innovation policy makers from the ten countries. This same group also serves as the Steering Committee for PA INNO. Financing for program activities is secured from EU programs, Nordic institutions and national and regional contributions.

Key features

of design and implementation:
Target groups:

- Clusters and business networks in the Baltic Sea Region (including small and large firms, research organizations)

- Other research and innovation nodes in the BSR

- Regional and national policy makers (working in the field of innovation and cluster policy, smart specialization and transnational collaboration)

- European Commission (parts addressing policy fields mentioned above)

Level of There is no fixed financial support for flagships financial with EU's macroregional strategies. Rather, support: flagships must secure financing from EU programs (including territorial cooperation programs, Horizon 2020, etc.), other 
Table A2.6 (continued)

\begin{tabular}{|c|c|c|}
\hline & $\begin{array}{l}\text { Level of } \\
\text { financial } \\
\text { support: } \\
\text { Timescale: }\end{array}$ & $\begin{array}{l}\text { multinational sources (such as Nordic } \\
\text { institutions), and from participating countries } \\
\text { (on national and regional levels). Between } \\
2011 \text { and 2013, BSR Stars secured financing } \\
\text { from the BSR Program, the Nordic Council } \\
\text { of Ministers, and national sources totaling } \\
\text { nearly } € 7 \text { million ( } \$ 7.6 \text { million). } \\
\text { The BSR Stars program is planned to run until } \\
2020 \text {. }\end{array}$ \\
\hline $\begin{array}{l}\text { Main results/ } \\
\text { lessons learned: }\end{array}$ & $\begin{array}{l}\text { BSR St } \\
\text { since its } \\
\text { of the S } \\
\text { networl } \\
\text { and De } \\
\text { BSR In } \\
\text { matchn } \\
\text { implem } \\
\text { BONU } \\
\text { in: } \\
-\quad \text { the } \\
\text { net } \\
850 \\
-\quad \text { the } \\
\text { serv } \\
-\quad \text { the } \\
\text { in a } \\
-\quad \text { the } \\
\text { nat } \\
\text { Inn } \\
201\end{array}$ & $\begin{array}{l}\text { rs has implemented a number of activities } \\
\text { launch in 2010, including: implementation } \\
\text { tarDust project, development of the Demola } \\
\text {, initiation of the Central Baltic Testbed } \\
\text { nonstration Facility, development of the } \\
\text { ovation Express concept (including annual } \\
\text { aking events and transnational calls), and } \\
\text { ntation of two innovation calls within the } \\
\text { research program. These activities have resulted } \\
\text { engagement of more than } 50 \text { clusters or business } \\
\text { orks, } 15 \text { universities, more than } 900 \text { SMEs and } \\
\text { students in transnational innovation activities } \\
\text { development of more than } 40 \text { new product and } \\
\text { ice concepts } \\
\text { attraction of more than } € 11 \text { million (\$11.9 million) } \\
\text { dd-on financing to these actors } \\
\text { mobilization of } € 7.5 \text { million ( } \$ 8.1 \text { million) of } \\
\text { onal financing to transnational calls (BONUS } \\
\text { vation call } 2012 \text { and Innovation Express call } \\
\text { ) }\end{array}$ \\
\hline
\end{tabular}

- The scope of activities pursued within BSR Stars is highly dependent on both political priorities within participating countries, and on financing levels. As transnational activities are generally still 'out of scope' for regional and national organizations, BSR Stars is reliant on financing from EU and other multinational sources.

- BSR Stars helps to engage actors in transnational innovation activities and develop these activities into longer-term partnerships. The results of such 'soft infrastructure' programs are in the form of closer-knit networks and increased trust and social capital (which are difficult to measure), as well as in the form of increased 
Table A2.6 (continued)

Main results/ lessons learned: stakeholder engagement, development of prototypes and increased investment. It is difficult to measure how these results contribute to increased integration, innovation and productivity growth in the region. For this reason, the program works with an 'effect logic' - describing how certain activities and outputs are foreseen to contribute to particular outcomes and effects over time.

Notes: $\quad$ BONUS $=$ Joint Baltic Sea Research and Development Program; BSR $=$ Baltic Sea Region; $\mathrm{CeBa}=$ Central Baltic Testbed and Demonstration Facility; DK = Denmark; $\mathrm{EU}=$ European Union; EUSBSR = European Strategy for the Baltic Sea Region; $\mathrm{PA}$ INNO = priority area innovation; $\mathrm{SE}=$ Sweden; SMEs = small- and medium-sized enterprises.

Source: Author.

Table A2.7 Tools for regional cooperation and integration: hard infrastructure

\begin{tabular}{|c|c|c|c|}
\hline Type of Tool & $\begin{array}{l}\text { Implemented } \\
\text { at EU level } \\
\text { (included } \\
\text { BSR-specific } \\
\text { instruments) }\end{array}$ & $\begin{array}{l}\text { Implemented at BSR } \\
\text { (or Nordic) level }\end{array}$ & $\begin{array}{l}\text { Implemented at } \\
\text { national level }\end{array}$ \\
\hline $\begin{array}{l}\text { Integration } \\
\text { (hard } \\
\text { infrastructure) }\end{array}$ & $\begin{array}{ll}\text { - } & \text { TEN-T } \\
\text { policy and } \\
\text { program } \\
\text { - } & \text { European } \\
\text { Spallation } \\
\text { Source }\end{array}$ & & $\begin{array}{ll}\text { - } & \text { Transport } \\
\text { infrastructure } \\
\text { - } & \text { Energy } \\
\text { infrastructure } \\
\text { - Research } \\
\text { infrastructure }\end{array}$ \\
\hline Name of Tool: & \multicolumn{3}{|c|}{$\begin{array}{l}\text { Trans-European Network for Transport infrastructure } \\
\text { (TEN-T) policy and the Connecting Europe Facility (CEF) }\end{array}$} \\
\hline $\begin{array}{l}\text { Type of Tool: } \\
\text { Implementation } \\
\text { Level: }\end{array}$ & \multicolumn{3}{|c|}{$\begin{array}{l}\text { European Commission - Directorate General Mobility and } \\
\text { Transport }\end{array}$} \\
\hline $\begin{array}{l}\text { Motivation and } \\
\text { Aim: }\end{array}$ & \multicolumn{3}{|c|}{$\begin{array}{l}\text { At the beginning of the } 1990 \text { s, the then } 12 \text { member states } \\
\text { had decided to set up an infrastructure policy at community } \\
\text { level to support the functioning of the internal market } \\
\text { through continuous and efficient networks in the fields of }\end{array}$} \\
\hline
\end{tabular}


Table A2.7 (continued)

Motivation and Aim:

Profile: transport, energy and telecommunications. The result was the first set of 'community guidelines' for the development of a Trans-European Network in the transport sector (adopted by the European Parliament and Council in 1996), which established a 'master plan' for connecting national networks of all transport modes. The guidelines determine projects' eligibility for EU funding (through the Connecting Europe Facility (CEF)). CEF financial support has two main forms: grants, which are non-reimbursable investments from the EU budget; and contributions to innovative financial instruments, developed together with entrusted financial institutions such as the European Investment Bank.

Since 1996, the Trans-European Network for Transport infrastructure has regularly updated the guidelines for TEN-T and the CEF. Other EU funds - notably the Cohesion Fund and the ERDF - also contributed to developing the TEN-T. At the same time as the guidelines helped prioritize project funding, they also constituted a reference framework for member states' infrastructure policy.

The concept of 'core network corridors' was introduced to facilitate the coordinated implementation of the core network. They bring together public and private resources and concentrate EU support from the CEF, particularly to remove bottlenecks, build missing cross-border connections and promote modal integration and interoperability. They also aim to: (1) integrate rail freight corridors; (2) promote clean fuel and other innovative transport solutions; (3) advance telematics applications for efficient infrastructure use; (4) integrate urban areas into the TEN-T; and (5) enhance safety. These nine core network corridors are strong means for the European Commission not only to boost investments but also to advance and showcase the achievement of wider EU transport policy objectives.

As of January 2014, the European Union has a new transport infrastructure policy that connects the continent from East to West, North to South. This policy aims to close the gaps between member states' transport networks, remove bottlenecks that still hamper the smooth functioning of the internal market and overcome technical barriers such as incompatible standards for railway 
Table A2.7 (continued)

Profile:

Key features

of design and implementation:

traffic. It promotes and strengthens seamless transport chains for passenger and freight, while keeping up with future technological trends. The policy, and the accompanying Connecting Europe Facility, will help the economy in its recovery and growth, with a budget of $€ 26$ billion ( $\$ 28$ billion) up to 2020 . This new policy framework brings innovations and significant progress in a number of areas: governance at European level, a strong legal form, a genuine network approach, a powerful instrument for TEN-T funding, etc.

The European Commission nominated a European Coordinator for each of the nine core network corridors. It has also nominated European Coordinators for two horizontal priorities: the European Rail Traffic Management System (ERTMS) and Motorways of the Sea. These European coordinators - individuals with long-standing experience in transport, financing and in European politics - will lead the drive to build the core network corridors, which represent the strategic heart of the TEN-T and therefore deserve a concentrated amount of effort and attention for their financing, cooperation efficiency and quality.

A work plan will be drawn up for each corridor that will set out the current status of its infrastructure, a schedule for removing physical, technical, operational and administrative bottlenecks, and an overview of the financial resources (EU, international, national, regional and local; public and private).

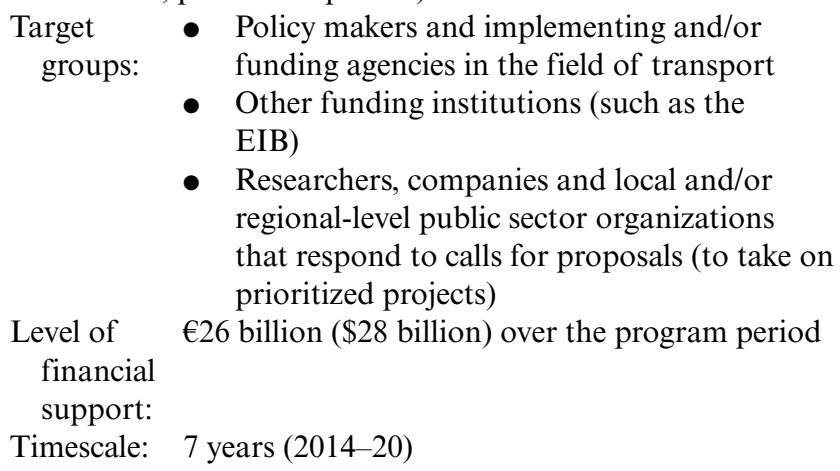


Table A2.7 (continued)

Main results/ lessons learned:
- The smooth connection between the east and the west of Europe in the aftermath of the 2004 enlargement has been one of the most important achievements of TEN-T policy in the last decade.

- Over time, the guidelines (and priorities) established in the TEN-T policy have been used to guide transport policy in member states, creating a more integrated strategy (and investments) for European transport infrastructure.

- Having a policy with an accompanying financing instrument (the Connecting Europe Facility) has helped drive implementation of prioritized projects. The increased use of various EU funds (i.e. the CEF, the Cohesion Fund and the ERDF) in connection with one another has provided even stronger mobilization and action on prioritized projects.

- The establishment of 'core network corridors' (each with its own coordinator to drive activities) helps to focus efforts on addressing issues/prioritized projects in each corridor. Through such a governance structure, more attention and more significant investments are made in particular areas, speeding progress and helping achieve targeted results.

Notes: $\quad$ BSR = Baltic Sea Region; $\mathrm{CEF}=$ Connecting Europe Facility EIB $=$ European Investment Bank; ERDF = European Regional Development Fund; ERTMS = European Rail Traffic Management System; EU = European Union; TEN-T = Trans-European Network for Transport infrastructure.

Source: Author. 
Table A2.8 Tools for regional cooperation and integration: trade and foreign direct investment

\begin{tabular}{l|l|l|l}
\hline $\begin{array}{l}\text { Type of } \\
\text { Tool }\end{array}$ & $\begin{array}{l}\text { Implemented at EU } \\
\text { level (included BSR- } \\
\text { specific instruments) }\end{array}$ & $\begin{array}{l}\text { Implemented at } \\
\text { BSR (or Nordic) } \\
\text { level }\end{array}$ & $\begin{array}{l}\text { Implemented at } \\
\text { national level }\end{array}$ \\
\hline $\begin{array}{l}\text { Trade } \\
\text { and FDI }\end{array}$ & $\begin{array}{l}\text { Enterprise } \\
\text { Europe Network } \\
\text { (and cluster } \\
\text { contact points) }\end{array}$ & $\begin{array}{l}\text { BSR } \\
\text { investment } \\
\text { promotion } \\
\text { agencies } \\
\text { collaboration }\end{array}$ & $\begin{array}{l}\text { National and } \\
\text { regional export } \\
\text { promotion and } \\
\text { inward investment } \\
\text { agencies (some } \\
\text { of which have } \\
\text { activities targeting } \\
\text { clusters) }\end{array}$ \\
\hline
\end{tabular}

Notes: $\quad$ BSR $=$ Baltic Sea Region $; \mathrm{EU}=$ European Union; FDI $=$ foreign direct investment.

Source: Author.

\section{NOTE}

1. Based on the details presented in the description of tools, found in Appendix 2, and on perspectives collected in the field study in Lithuania and Latvia. 